\title{
Inflammation and Angiogenesis in Diabetic Retinopathy
}

\author{
Ying Yang, Ying Zhang and Yiping Li \\ Department of Endocrinology and Metabolism, \\ Yunnan Province 2nd Hospital, \\ Kunming, \\ PR China
}

\section{Introduction}

Diabetic retinopathy (DR) is a significant cause of global blindness; a major cause of blindness in the world.There is emerging evidence that retinopathy is initiated and propagated by inflammation and angiogenesis. Increased cytokines and growth factors, in conjunction with redox stress, contribute to the development and progression of DR of abnormalities of endothelial cells and pericytes in DR.

The four traditional metabolic pathways involved in the development of DR include: increased polyol pathway flux, advanced glycation end-product formation, activation of protein kinase Cisoforms and hexosamine pathway flux. These pathways individually and synergistically contribute to angiogenic growth factors, anti-angiogenic factors resulting in significant microvascular blood retinal barrier remodeling. The pathways are associated with inflammation and angiogenesis,either. Preventing or delaying the blindness associated with these intersecting abnormal metabolic pathways may be approached through strategies targeted to reduction of tissue inflammation. Understanding these abnormal metabolic pathways and the accompanying inflammation and angiogenesis mayprovide both the clinician and researcher a new concept of approaching this complicated disease process.

\section{Diabetic Retinopathy (DR)}

$\mathrm{DR}$ is associated with the following structural features: basement membrane (BM) thickening, pericyte loss,microaneurysms, intraretinal microvascular abnormalities(IRMA), diabetic macular edema (DME) and pre-retinal neovascularization,processes which can lead to blindness through hemorrhage and tractional retinal detachment ${ }^{1}$. Retinal endothelial cells (EC) are supported and sealed by a nearly equal number of pericytes in the retinal optic nerve fiber, inner and outer plexiform and choroidal layers creating a blood retinal barrier (BRB) of closed capillaries ${ }^{1,2}$.

The vascular disruptions of DR/DME are characterized by abnormal vascular flow, disruptions in permeability,and/or closure or nonperfusion of capillaries. 
A hallmark of early DR is the change in the structure and cellular composition of the microvasculature ${ }^{3}$.

In early stages of DME, breakdown of the inner blood-retinal barrier may occur, resulting in accumulation of extracellular fluid in the macula ${ }^{4,5}$.Pericytes are essential cellular components in the regulation of retinal capillary perfusion, and damage to these cells in diabetes leads to altered retinal hemodynamics, including abnormal autoregulation of retinal blood flow ${ }^{6}$. Loss of retinal pericytes represents another early microaneurysm formation ${ }^{7-9}$.

There is evidence that retinal leukostasis may also play an important role in the pathogenesis of DR. Leukocytes possess large cell volume, high cytoplasmic rigidity, a natural tendency to adhere to the vascular endothelium, and a capacity to generate toxic superoxide radicals and proteolytic enzymes ${ }^{10}$. In diabetes, there is increased retinal leukostasis, which affects retinal endothelial function, retinal perfusion, angiogenesis, and vascular permeability. And, leukocytes in diabetes are less deformable, a higher proportion are activated, and they may be involved in capillary nonperfusion, endothelial cell damage, and vascular leakage in the retinal microcirculation ${ }^{10}$. A study showed that diabetic vascular leakage and nonperfusion are temporally and spatially associated with retinal leukostasis in streptozotocin induced diabetic rats ${ }^{11}$. There are many capillary occlusions by leukocytes and capillary dropout or degeneration associated with leukocytes in the diabetic retina ${ }^{10}$. Serial acridine orange leukocyte fluorography and fluorescein angiography(FA) show trapped leukocytes directly associated with areas of downstream nonperfusion in the diabetic retinal microcirculation ${ }^{10}$.

A number of proangiogenic, angiogenic and antiangiogenic factors are involved in the pathogenesis and progression of diabetic retinal disease, Vascular Endothelial Growth Factor (VEGF) being one of the most important. Other growth factors, which are known to participate in the pathogenesis of the disease, are: Platelet Derived Growth Factor (PDGF), Fibroblast Growth Factor (FGF), Hepatocyte Growth Factor (HGF), Transforming Growth Factor (TGF), Placental Endothelial Cell Growth Factor (PlGF), Connective Tissue Growth Factor (CTGF). Other molecules that are involved in the disease mechanisms are: intergrins, angiopoietins, protein kinase $\mathrm{C}$ (PKC), ephrins, interleukins, leptin, angiotensin, monocyte chemotactic protein (MCP), vascular cell adhesion molecule (VCAM), tissue plasminogen activator (TPA), and extracellular matrix metalloproteinases (ECM-MMPs).

\section{Vascular Endothelial Growth Factor (VEGF)}

The VEGFs are a family of proteins that are mitogenic for vascular endothelial cells and increase vascular permeability. VEGF is important in fetal vascular development,with VEGF levels diminishing after birth. VEGF is expressed by retinal glial cells ${ }^{12}$ and vascular endothelial cells ${ }^{13}$. VEGF is secreted by numerous ocular cell types ${ }^{14}$, and increased levels of VEGF have been detected in ocular fluids of patients with proliferative diabetic retinopathy ${ }^{15}$. In vivo, administration of neutralizing VEGF antibodies to experimental animals reverses high-glucose-induced vascular hyperpermeability ${ }^{16}$, which is an early manifestation of endothelial dysfunction in diabetic patients ${ }^{17}$.

VEGF expression is regulated largely by hypoxia, but it also accumulates in the retina early in diabetes, before any retinal hypoxia is yet apparent ${ }^{18-20}$. It is produced by multiple cell 
types in the retina in diabetes, including ganglion cells, Mueller cells, and pericytes. Repeated injections of high concentrations of VEGF in the eyes of nondiabetic monkeys result in retinal changes which in some ways resemble those in the early stages of diabetic retinopathy, including vascular tortuosity and microaneurysm ${ }^{21}, 22$. Genetic factors are important in the pathogenesis of DR; there is a clear association of increased expression of VEGF with DR as well as numerous VEGF polymorphisms that are linked to increased VEGF levels and DR. ${ }^{23}$ Their result has demonstrated that the development of different stages of diabetic retinopathy is closely correlated with an increased VEGF level in the retina ${ }^{24}$.Clinical trials using anti-VEGF therapies are showing promising results against stages of diabetic retinopathy ${ }^{25}$.

VEGF is a potent vascular permeability factor, and VEGF upregulation has been linked to neovascular eye diseases including diabetic retinopathy ${ }^{23}$. VEGF-induced neovascular changes have previously been demonstrated on animal models based on increasing VEGF levels through implants26, recombinant adenovirus-mediated VEGF expression ${ }^{27,28}$, or transgenic technologies 29,30 .

In the eye, one of the earliest signs of diabetic retinopathy is retinal capillary occlusion, blocking blood flow and generating capillary-free areas ${ }^{31}$. Hypoxic conditions could develop in these capillary-free areas, and this in turn could induce the upregulation of angiogenic factor production, such as VEGF and intercellular adhesion molecules 32,33 . The increased concentration of angiogenic factors would then cause vascular changes including vascular dilatations, tortuous blood vessels, microaneurysms, and endothelial cell proliferation. Subsequently,over an extended period of time, these changes could result in the development of poorly matured leaky vessels ${ }^{34}$, 35.Previous histological studies have demonstrated a strong correlation between endothelial cell proliferation, pericyte loss, and the development of microaneurysm ${ }^{36}$. Incidentally, VEGF, which is a known factor of endothelial cell proliferation, has also been shown to promote pericyte detachment and $\operatorname{loss}^{37}$.

Troglitazone and rosiglitazone, another thiazolidinediones (TZD), increase VEGF mRNA levels in 3T3-L1 adipocytes.Although increased VEGF may be beneficial for subjects with macroangiopathy and troglitazone is currently not available for clinical use, vascular complications, especially diabetic retinopathy, must be followed with great caution in subjects treated with TZD 38 .

Federico et $\mathrm{al}^{39}$ tested selective PPARa and PPARY synthetic agonists potential ability to stimulate neoangiogenesis in well-established in vitro and in vivo assays. They found that specific and selective activation of PPARa and PPAR $\gamma$ leads to increased production of VEGF, a prototypical angiogenic agent, and formation of endothelial tubules when endothelial cells are co-cultured with interstitial cells. In vivo, PPARa and PPARY synthetic agonists stimulate angiogenesis in the mouse corneal neovascularization assay, whereas fibrates and TZDs are unable to induce angiogenesis in the same experimental setting. PPARa- and PPARY-angiogenic process is associated with increased expression of VEGF and increased phosphorylation of endothelial nitric oxide (NO) synthase(eNOS) and Akt. Finally, it may be inhibited by blocking VEGF activity. The ability of PPARa and PPARY agonists to induce neoangiogenesis might have important implications for the clinical and therapeutic management of type 2 diabetes ${ }^{39}$. 


\section{Pigmented Epithelial Derived Factor (PEDF)}

PEDF is a member of the serine protease inhibitor (serpin) superfamily with neurotrophic and antiangiogenic properties, and a decreased level of PEDF in the eye is important in the pathogenesis of proliferative $\mathrm{DR}^{40}$. In the retina, angiogenesis is regulated by two counterbalancing systems: angiogenic stimulators, such as VEGF, and angiogenic inhibitors, such as angiostatin and pigment epithelium-derived factor (PEDF) ${ }^{40}$.

PEDF is a natural extracellular component of the retina and has been found in the vitreous and aqueous humors. Decreased levels of PEDF were reported in the ocular fluids of patients with angiogenic eye diseases ${ }^{41}$. PEDF has potent antiangiogenic activity in retinal EC growth and migration and suppressed ischemia-induced retinal neovascularization ${ }^{42}$.

Pericyte loss is one of the earliest hallmarks of DR and an important reason for pericyte loss is reactive oxygen species (ROS) ${ }^{43}$. In DR, PEDF has a novel benefit since PEDF protects retinal pericytes against oxidative stress-induced injury through its anti-oxidative properties, which might slow the development of diabetic retinopathy ${ }^{43}$.PEDF protects against high glucose or ROS induced pericyte apoptosis and dysfunction through its antioxidative properties via induction of glutathione ${ }^{44}$.

Guoquan et $\mathrm{al}^{45}$ compared susceptibilities of Sprague Dawley(SD) and Brown Norway(BN) rats with ischemia-induced retinal neovascularization. They found that the hyperoxiatreated $\mathrm{BN}$ rats showed a significant reduction in retinal PEDF and a substantial increase of VEGF at both the protein and RNA levels, resulting in an increased VEGF-to-PEDF ratio. The results suggested that $\mathrm{BN}$ rats developed more severe retinal neovascularization, which correlated with a greater increase of the VEGF-to-PEDF ratio in BN than in SD rats ${ }^{45}$.

PEDF, a potent inhibitor of angiogenesis, has been found to be involved in the pathogenesis of $\mathrm{PDR}^{46}, 47$. It is well known that there are quite a few stimulators and inhibitors of angiogenesis in the eye; among them, VEGF has been identified as a primary angiogenic stimulator ${ }^{48}$ and PEDF as a major angiogenic inhibitor ${ }^{47}$. The time course of the VEGF-toPEDF ratio change correlated with the development and progression of retinal neovascularization. The VEGF-to-PEDF ratio represented a dynamic balance between angiogenic stimulators and inhibitors; and disturbance of the balance played a key role in the pathogenesis of DR $45,49,50$. In vitro study revealed that lowering of the VEGF-to-PEDF mRNA ratio could inhibit the migration of uveal melanoma cells ${ }^{51}$.

Additionally, PEDF induces the ERK signal cascade which contributes to retinal pigment epithelial cell cytoprotection against oxidative stress ${ }^{52}$. Thus, retinal cells including the BRB capillaries and their supportive and protective pericytes may possess a system capable of efficiently responding to $\mathrm{PEDF}^{43,}$.

Retinal ischemia induces intraocular neovascularization,presumably by stimulating the expression of angiogenic growth factors and by inhibiting the release of antiangiogenic cytokines ${ }^{53}, 54$. Vitreal levels of angiogenic growth factors have been shown to be directly associated with the degree of retinal angiogenesis 15,55 . PEDF protects cerebellar granule cells against neurotoxic agents 56 and is also called early population doubling level cDNA-1 (EPC- 
1), reflecting its upregulation during cell cycle arrest (G0) in young but not in senescent cultured fibroblasts 57 .

PEDF has been shown to be a highly effective inhibitor of angiogenesis in animal and cell culture models. The production of PEDF was decreased by hypoxia ${ }^{47}$, which is also a central pathogenic stimulus in PDR. Immunoneutralization of PEDF diminished the ability of cadaveric human vitreous to inhibit migration of endothelial cells, thereby demonstrating that a loss of PEDF is functionally important in mediating angiogenic properties of human vitreous ex vivo. Most importantly, systemically administered PEDF prevented aberrant blood vessel growth in a murine model of ischemia-induced retinopathy58.

PEDF has been shown to be a major antiangiogenic growth factor in the mammalian eye. Joachim $^{41}$ et al analyzed the in vivo regulation of PEDF in patients with and without hypoxic eye disease. Their data strongly support the concept that retinal angiogenesis is induced by loss of the major angiogenesis inhibitor in the eye, PEDF, in combination with an increased expression of angiogenic growth factors such as VEGF. These findings suggest that substitution of angiogenesis inhibitors may be an effective approach in the treatment of PDR 41

In the study of $\mathrm{Zhi}^{59}$ et al ,diabetic rats and control animals were randomly assigned to receive perindopril or vehicle for 24 weeks, and bovine retinal capillary endothelial cells (BRECs) were incubated with normal or high glucose with or without perindopril. The results showed the VEGF-to-PEDF ratio was increased in the retina of diabetic rats; perindopril lowered the increased VEGF-to-PEDF ratio in diabetic rats and ameliorated the retinal damage. In BRECs, perindopril lowered the hyperglycemia-induced elevation of VEGF-to-PEDF ratio by reducing mitochondrial ROS and the decreased ROS production was a result of perindopril induced upregulation of PPARY and UCP-2 expression ${ }^{59}$.

Although VEGF is the major factor in the initiation of advanced stages of diabetic retinopathy, it is increasingly recognized that PIGF is a significant factor in promoting the aberrant angiogenesis characteristic of a variety of pathological states.

\section{Adiponectin (ADPN)}

The adipocyte derived factor ADPN is an insulin sensitivity activator, and is correlated to retinal redox stress and remodeling in metabolic syndrome and T2DM. Low levels of serum ADPN levels were found to be correlated with the severity of retinopathy ${ }^{60}$. Insulinsensitizing agents reduce pathological retinal microvessel formation through ADPN mediated modulation of tumor necrosis factor alpha (TNF $\alpha$ ) production ${ }^{61}$. ADPN' s effect on diabetic retinopathy is not clear. However, ADPN induces eNO production by stimulating phosphorylation and activation of eNOS. ADPN inhibits specific binding of oxidized LDL and its uptake by macrophages. ADPN possesses anti-inflammatory properties and thus may negatively modulate the process of atherogenesis ${ }^{62,63}$.

In the early phase of diabetic retinopathy, hyperglycemia initiates endothelial cell injury, retinal vessel loss, and ischemia, as well as changes in leukocyte adhesion to the vascular endothelium ${ }^{64}, 65$. These conditions subsequently lead to the overproduction of various proangiogenic factors and proinflammatory cytokines, which, in turn, promotes abnormal 
neovascular changes ${ }^{66}$. The primary goal for treatment of ischemic retinopathy is to preserve vision through the inhibition of abnormal neovascularization and vascular damage.

Adiponectin is a circulating adipose-derived cytokine with antiinflammatory properties ${ }^{67}$, 68.In animal models,adiponectin deficiency is associated with the increased inflammatory responses under conditions of stresses including overnutrition and ischemic insult 69,70 . In addition, adiponectin has been shown to protect against the development of various diseases including detrimental cardiac and vascular remodeling,ischemic stroke and increased albuminuria ${ }^{69}, 71-74$. In human populations, circulating adiponectin levels inversely correlate with the inflammatory marker C-reactive protein levels in blood stream $67,75,76$. Low plasma adiponectin levels are associated with the increased prevalence of type 2 diabetes and its macrovascular complications including ischemic heart disease $63,67,77$.

Clinical studies regarding the relationship between plasma adiponectin level and retinopathy in diabetes have been inconclusive ${ }^{78,} 79$. Higuchi et al investigated whether adiponectin affects the retinal vascularization and inflammation in a mouse model of ischemia-induced retinopathy. When neonatal mice were subjected to ischemia-induced retinopathy, pathological retinal neovascularization during ischemia was exacerbated in adiponectin-knockout (APN-KO) mice compared with wild-type mice. APN-KO mice also exhibited increased leukocyte adhesion and tumor necrosis factor (TNF)-a expression in hypoxic retina. Adenovirus-mediated overexpression of adiponectin attenuated hypoxiainduced pathological retinal neovascularization by $35 \%$ in wild-type mice and by $40 \%$ in APN-KO mice and leukostasis by $64 \%$ in wild-type mice and by $75 \%$ in APN-KO mice, which were associated with reduced TNF-a production. TNF-a blockade diminished the enhanced pathological neovascularization in APN-KO mice, and the inhibitory effects of adiponectin overexpression on retinal neovascularization and leukocyte adhesion were abolished in mice lacking TNF-a. These data provide evidence that adiponectin protects against retinal vessel injury following pathological stimuli through modulation of TNF-a inflammatory responses 80 .

ADPN suppresses adverse effects of inflammatory cytokines and reduces oxidative stress induced by oxidized LDL or high glucose in $\mathrm{EC}^{62,}{ }^{63}$. ADPN inhibits VEGF-stimulated human coronary artery EC migration via cAMP/PKA dependent signaling including VEGFinduced generation of ROS, which implicates it as an important role in vascular processes associated with diabetes. Because ADPN is known to act as an antioxidant, antiinflammatory, antiapoptotic and antifibrotic protein then its low levels may predispose it to a loss of any or all of the above known protective features of ADPN and directly or indirectly affect the capillary BRB including the pericyte. Importantly, ADPN may be used in the future as an early candidate biomarker of DR in CMS and T2DM.

\section{Leptin}

Not all patients with poor control of diabetes over long periods of time, develop retinopathy, suggesting the involvement of other mechanisms. The adipose tissue is an important endocrine organ that secretes many biologically active substances such as free fatty acids, adiponectin, and interleukin (IL)-6. They are collectively termed adipocytokines ${ }^{81}$. Leptin is one of adipocytokines, acting directly on the hypothalamus, thereby regulating food intake and energy expenditure ${ }^{82}$. The leptin receptor (Ob-R) is a 
single transmembrane protein that belongs to the gp130 family of cytokine receptor superfamily. The leptin receptor has several alternatively spliced isoforms, one of which, a biologically active $\mathrm{Ob}-\mathrm{Rb}$ isoform, is expressed not only in the hypothalamus but also in a variety of peripheral tissues, suggesting the direct action of leptin in the periphery. The peripheral actions of leptin include the activation of platelet aggregation, the modulation of immune function 83 , and the stimulation of vascular endothelial cell proliferation and angiogenesis ${ }^{84}, 85$. Upon binding to $\mathrm{Ob}-\mathrm{Rb}$, leptin has been shown to activate signal transducers and activators of transcription (STAT).

A study has revealed that plasma leptin concentrations are elevated significantly in patients with proliferative diabetic retinopathy relative to those with nonproliferative retinopathy ${ }^{86}$. Furthermore, vitreous leptin concentrations are higher in patients with proliferative diabetic retinopathy or retinal detachment ${ }^{87}$.

Using the retinopathy of prematurity model, a mouse model of ischemia-induced retinal neovascularization, Eri Suganami ${ }^{88} \mathrm{et}$ al have demonstrated more pronounced retinal neovascularization in 17-day-old transgenic mice overexpressing leptin than in age-matched wild-type littermates. Leptin receptor expression was also detected in primary cultures of porcine retinal endothelial cells, where it upregulated VEGF mRNA expression. This effect was thought to be mediated at least partly through the activation of signal transducers and activators of transcription(STAT)3, because adenoviral transfection of the dominant negative form of STAT3 abolished the leptin-induced upregulation of VEGF mRNA expression in retinal endothelial cells. This study provides evidence that leptin stimulates the ischemiainduced retinal neovasucularization possibly through the upregulation of endothelial VEGF88.

\section{Insulin-like Growth Factor-1 (IGF-1)}

Similar to VEGF, the activation of IGF-1 also increases PKC activation, so IGF-1 may be regulated by oxidative stress via the PKC pathway ${ }^{89}$. Retinal IGF-1 mRNA levels are lower in the human and diabetic rat when compared to age matched non-diabetic controls ${ }^{90}$ and IGF-1 can have direct mitogenic effects on retinal EC 60 .IGF-1 can stimulate glucose transport into retinal microvascular EC via activation of PKC and can modulate the expression and activity of $\mathrm{VEGF}^{91}$.

Growth hormone and IGF-I have been suspected of playing a role in the progression of diabetic retinopathy. In a previous era, hypophysectomy was shown to lead to regression of proliferative retinopathy in a study of 100 patients $^{92}$. Similarly, diabetic dwarfs with low systemic IGF-I levels due to growth hormone deficiency have a reduced incidence of proliferative DR compared with age- and sex matched diabetic patients. Such observations have raised interest in the use of growth hormone-inhibitory and antiproliferative somatostatin analogs to treat severe proliferative DR, however, a growth hormone receptor antagonist, pegvisomant, failed to induce regression of neovascularization ${ }^{93}$. This negative result may have occurred because the treatment was initiated too late; treatment may need to have started prior to the development of proliferative DR. In another small-scale trial (23 patients), octreotide (a somatostatin analog) treatment reduced the requirement for laser photocoagulation compared with conventional treatment in patients with either severe NPDR or early proliferative DR ${ }^{94}$. Over the 15-month study, only1 of 22 octreotide-treated patients required photocoagulation compared with 9 of 24 conventionally treated patients. 


\section{Interleukin-1 Beta (IL-1 $\beta$ )}

Levels of the proinflammatory cytokine, IL-1 $\beta$, are known to be increased in retinas from diabetic rats ${ }^{95-97}$. Intravitreal injection of IL-1 $\beta$ or exposure of retinal endothelial cells to the cytokine in vitro was shown to be capable of causing degeneration of retinal capillary endothelial cells ${ }^{98}$, but the relevance of these findings to capillary degeneration in vivo is not clear because the levels of IL-1 $\beta$ likely were pharmacologically high. The role of IL- $1 \beta$ in the pathogenesis of diabetic retinopathy recently has been more directly studied using diabetic mice in whom the enzyme responsible for IL-1 $\beta$ production was inhibited or in whom the IL-1 $\beta$ receptor was deleted. IL-1 $\beta$ is the predominant product of caspase-1, and the biological activity of IL-1 $\beta$ is mediated by binding to the cell surface receptor, IL-1R1. Activity of caspase- 1 is increased in retinas of diabetic mice, galactosefed mice, and diabetic humans, and in retinal Müller cells incubated in elevated glucose concentration ${ }^{99}$. Inhibition of caspase-1 using minocycline inhibited the diabetes induced increase in IL-1 $\beta$ and decreased degeneration of retinal capillaries in those animals ${ }^{95}$. Likewise, inhibition of IL-1 $\beta$ signaling using IL-1 $\beta$ receptor knock-out mice protected the animals from diabetes-induced retinal pathology at 7 months duration of diabetes ${ }^{95}$. The results indicate that activation of caspase- 1 and subsequent production of IL-1 $\beta$ play an important role in the development of diabetes induced retinal pathology. One known action of IL-1 $\beta$ is to activate NF-K B.

IL-1 $\beta$ gene expression is known to reside in EC and glial cells and its expression is significantly upregulated in high glucose conditions allowing for BRB allowing inflammatory cells to increase their migration across the $\mathrm{BRB}^{98}$.

IL-1 $\beta$ is known to increase the expression of VEGF in retinal EC, and induces the expression of various genes whose promoters are regulated through complex interactions with $N F K B^{100}$. IL-1 $\beta$ has been found to be increased in streptozotocin diabetic rat models ${ }^{98}$ and IL$1 \beta$ accelerates apoptosis in retinal capillary cells, specifically pericytes, through activation of $\mathrm{NFKB}$, which is exacerbated by high glucose conditions ${ }^{101}$. NFK $\beta$ is a key regulator of antioxidant enzymes and can initiate transcription of genes involved in apoptosis and additionally increases downstream inflammatory cytokines ${ }^{101}$. Importantly, IL-1 $\beta$ activation-stimulation results in the translocation of NFKB from its cytosolic compartment to the nucleus where it initiates apoptotic genes and downstream inflammatory cytokines ${ }^{101}$.

Additionally, IL-1 $\beta$ is considered as one of the most potent stimuli for inducible NOS (iNOS), contributing to ongoing inflammation via induction of iNOS protein and augmentation of its activity $^{98}$. IL-1 $\beta$ receptor antagonism (IL-1 $\beta \mathrm{ra}$ ) in the retina and IL$1 \beta$ have been shown to interfere with the development of not only diabetic retinopathy but also pancreatic islet inflammation and beta cell apoptosis in humans with T2DM ${ }^{102}$.

\section{Interleukin-6 (IL-6)}

The IL-6 cytokine shares common characteristics with VEGF, in that both are induced by hypoxia and hyperglycemia, and both play a role in vascular inflammation, permeability and angiogenesis ${ }^{103}$. Human studies have demonstrated that both VEGF and IL-6 were elevated in aqueous humor of patients with DR and even higher in those with proliferative DR indicating that VEGF and IL-6 play important roles in the development of DR ${ }^{104}$. Even 
peripheral blood levels of IL-6 and TNF $\alpha$ were elevated in humans with DR with the highest elevations found in those with proliferative $\mathrm{DR}^{105}$. It has been shown that the AngIIinduced vascular alterations involved activation of NAD(P)H oxidase, IL-6, and increases in VEGF expression and further,that deletion of IL-6 prevented these effects of vascular inflammation in $\mathrm{DR}^{106}$.

\section{Monocyte Chemoattractant Protein (MCP-1)}

MCP-1 contributes to the recruitment of inflammatory cells (monocytes/monocyte derived macrophage/microglia) in injured tissue and ROS injury may play a role in DR and retinal detachment ${ }^{107}$. MCP-1 is a potential angiogenic factor in the proliferative phase of DR and is associated with proliferation $\mathrm{DR}^{107}$.Hyperglycemia increases the expression of MCP-1 in vascular $\mathrm{EC}^{63}$ and AGE-induced ROS generation induced the MCP-1 gene and mRNA expression $^{63}$. Recently, aqueous samples in humans with DR have revealed higher levels of MCP-1 and VEGF when compared to nondiabetic subjects and authors further state that inflammatory changes may precede the development of neovascularization in proliferative $\mathrm{DR}^{108}$.

\section{Vascular Cell Adhesion Molecule (VCAM)}

Many specific growth factors mediate angiogenic process of diabetic retinopathy. VCAM-1, a member of the immunoglobulin supergene family of cellular adhesion molecules, is involved in the recruitment of leukocytes, their adhesion to vascular endothelium, and their subsequent migration into surrounding tissue. Interestingly, the expression of VCAM-1 has been found in epiretinal membranes from diabetic patients with PDR109, 110. In addition, it has been demonstrated that VCAM-1 promotes angiogenesis both in vitro and in vivo111, 112.Olson et al. detected increased serum levels of VCAM-1 in diabetic patients with PDR 113 . Moreover, circulating levels of various adhesion molecules increase in patients with progressively worsening retinopathy, presumably as a result of shedding from both activated leukocytes and injured epithelium. However, systemic levels of VCAM-1 do not reflect the local production of VCAM-1 by the retina. Vitrectomy fluid samples obtained from diabetic patients with PDR are currently being used to explore indirectly

the retinal synthesis of several proteins, including growth factors, cytokines, and adhesion molecules. Two previous studies demonstrated that soluble VCAM-1 is increased in the vitreous cavity of diabetic patients with PDR compared with the vitreous of patients undergoing macular hole repair ${ }^{114}$ or from cadaveric eyes ${ }^{15}$.

\section{Connective Tissue Growth Factor (CTGF)}

The tissue repair process is regulated by a number of polypeptides including cytokines and growth factors. CTGF is a $38-\mathrm{kDa}$ cysteinerich polypeptide that was originally identified from conditioned medium of human umbilical vein endothelial cells (HUVECs) ${ }^{115}$. CTGF, considered to be a downstream mediator of transforming growth factor- $B$ (TGF- $B)^{116,117}$, is indicated to induce the production of extracellular matrix,such as collagen and fibronectin, and to cause fibrosis ${ }^{118}$. One study have shown that CTGF is overexpressed in the 
membranes of eyes with PDR119, suggesting that CTGF might be involved in the pathogenesis of PVR and PDR. In addition, A study revealed that CTGF is overexpressed also in the vitreous with PVR and PDR and additionally demonstrated that various types of vitreoretinal cells could be the sources of CTGF ${ }^{120}$.

Furthermore, CTGF has been recently indicated to be one of the regulators of angiogenesis. In vitro, CTGF has been demonstrated to have proangiogenic effects on Human umbilical vein endothelial cell ${ }^{121}$ and bovine aortic endothelial cells (BAECs) ${ }^{122}$, and in vivo, CTGF has been indicated to induce angiogenesis in rat corneal pocket implants ${ }^{123}$ and to be involved in tumor angiogenesis ${ }^{124}$ and choroidal neovascularization ${ }^{125,126}$

In the study of Takeshi et al, they demonstrated CTGF also stimulated the synthesis of fibronectin by hyalocytes and BRPEs without significant effect on collagen gel contraction by these cells. And CTGF promoted VEGF gene expression by hyalocytes and BRPEs. There was no significant correlation between the concentrations of CTGF and VEGF. These findings indicate that CTGF appears to be involved in the formation of proliferative membranes without direct regulation of their cicatricial contraction in the pathogenesis of proliferative vitreoretinal diseases. It is possible that CTGF has indirect effects by modulating the expression of VEGF127.

\section{Retinal Intercellular Adhesion Molecule-1 (ICAM-1) and CD18}

The retinal vasculature of diabetic humans contains increased numbers of leukocytes, a finding that coincides with the increased expression of ICAM-1 in retinal vasculature ${ }^{128}$. The phenomenon is also present in diabetic animal models and occurs whether the diabetes is spontaneous in nature or is induced $11,129,130$. The increased density of leukocytes in the retinal vasculature begins as early as 1 week following the onset of experimental diabetes and results in injury to the endothelium via a FasL-mediated mechanism; a process that leads to breakdown of the BRB 131,132. Retinal ischemia is a second sight-threatening diabetic complication. Histolopathological analyses have shown that areas of angiographic nonperfusion in vivo frequently co-localize to regions full of acellular capillaries, that is, basement membrane tubes devoid any viable endothelial cells or pericytes ${ }^{133}$.

The leukocytes that adhere to the diabetic retinal vasculature use specific adhesion molecules such as the integrin ligand CD18, which forms the invariable portion of the heterodimers Mac1(CD11a/CD18) and LFA-1 (CD11b/CD18) ${ }^{134}$. Leukocytes use CD18 to tether themselves to intercellular adhesion molecule-1 (ICAM-1) on the surface of diabetic retinal vasculature.

A work has established the role of CD18/ICAM-1 leukocyte adhesion in the pathogenesis of early diabetes-induced leukostasis and blood-retinal barrier breakdown ${ }^{131}$. The study of Antonia et al also showed that retinal leukostasis increased within days of developing diabetes and correlated with the increased expression of retinal intercellular adhesion molecule-1 (ICAM-1) and CD18135. Mice deficient in the genes encoding for the leukocyte adhesion molecules CD18 and ICAM-1 were studied in two models of diabetic retinopathy with respect to the long-term development of retinal vascular lesions. CD18-/- and ICAM$1-/-$ mice demonstrated significantly fewer adherent leukocytes in the

retinal vasculature at 11 and 15 months after induction of diabetes with STZ. And this condition is associated with fewer damaged endothelial cells and lesser vascular leakage. 
Galactosemia of up to 24 months causes pericyte and endothelial cell loss and formation of acellular capillaries. However, these changes are significantly reduced in CD18- and ICAM1-deficient mice. Basement membrane thickening of the retinal vessels is increased in longterm galactosemic animals independent of the genetic strain. Thus, the chronic, low-grade subclinical inflammation is responsible for many of the signature vascular lesions of diabetic retinopathy.These data highlight the central and causal role of adherent leukocytes in the pathogenesis of diabetic retinopathy ${ }^{135}$.

Attraction and adhesion of leukocytes to the vascular wall are important components of inflammatory processes. This leukostasis has been found to be significantly increased in retinas of diabetic animals, and might contribute to the capillary nonperfusion in diabetic retinopathy. Leukocyte stiffness has been reported to be increased in diabetes (decreased filterability) and to contribute to the development of capillary nonperfusion in retinal vessels 136, 137. Diabetes increases expression of ICAM-1 in retinas of animals 11and interaction of this adhesion molecule on retinal endothelia with the CD18 adhesion molecule on monocytes and neutrophils contributes to the diabetes-induced increase in leukostasis within retinal vessels ${ }^{11}$. Leukostasis has been postulated to be a factor in death of retinal endothelial cells in diabetes ${ }^{131}$.

White blood cells bind to ICAM-1 on the surface of endothelial cells as a component of a multistep process leading to adherence of the white blood cell to the endothelial wall ${ }^{11}$.This leukostasis is known to be increased in retinal blood vessels in diabetes, and this process is mediated via ICAM-111. ICAM-1 is upregulated by several stimuli, including VEGF, PARP activation, oxidative stress, and dylipidemia138-141, at least in part by NF-K B.Genetically modified C57B1/6J mice have been used to explore the roles of ICAM-1 and its ligand on white blood cells (CD18) in the pathogenesis of diabetes-induced retinal vascular disease ${ }^{135}$.

\section{NF-KB}

NF-K B is a widely expressed inducible transcription factor that is an important regulator of many genes involved in mammalian inflammatory and immune responses, proliferation and apoptosis. NF-K B is composed of homodimers and heterodimers, the most abundant and best-studied form in mammalian cells consisting of the p65 and p50 subunits. Diabetes has been found to cause migration of the p65 subunit into the nucleus of retinal pericytes ${ }^{101}$, and of the p50 subunit into nuclei of retinal endothelial cells, pericytes, ganglion cells, and cells of the inner nuclear layer ${ }^{142}$.

Evidence in support of an important role of NF-K B in the pathogenesis of early stages of diabetic retinopathy is twofold. First, inhibition of proteins whose expression is regulated by NF-K B (such as iNOS and ICAM) inhibit diabetes induced degeneration of retinal capillaries (described below).Second, compounds known to inhibit NF-K B likewise inhibit the development of the retinopathy. For example, several different antioxidants which inhibit the development of capillary degeneration and pericyte loss in retinas of diabetic rats ${ }^{143}$ also inhibit the diabetes-induced activation of retinal NF-K B ${ }^{138}$. Likewise, low-intermediate doses of salicylates (aspirin, sodium salicylate, and sulfasalazine) which inhibited NF-к B activation in retinas of diabetic rats, also inhibited expression of inflammatory mediators like iNOS and ICAM-1, and capillary degeneration and pericyte loss in those animals ${ }^{143}, 144$. Aspirin is known to inhibit also production of prostaglandins, but salicylate and sulfasalazine have much less of 
this activity, suggesting that the common action of these salicylates to inhibit retinopathy in diabetes was not primarily mediated by inhibition of prostaglandins.

\section{5. iNOS}

Inducible isoform of nitric oxide synthase(iNOS) expression is regulated at least in part by NF-K B. Interestingly, experimental sympathectomy itself increases gene and protein expression of iNOS in retinas of nondiabetic rats 145 , suggesting that loss of sympathetic activity, such as which occurs in diabetes, might contribute to the upregulation of this inflammatory protein in the retina.

In retinas of diabetic animals, increased levels of nitric oxide products (nitrotyrosine, nitrite, nitrate) have been reported ${ }^{144-146}$. Upregulation of iNOS has been found in retinas of experimental diabetic rodents and patients in most studies $145-152$. Diabetes-induced alterations in expression of other isoforms of nitric oxide synthase also have been reported 153,154 . A possible role of iNOS in the pathogenesis of diabetic retinopathy is suggested by the studies of aminoguanidine. Aminoguanidine is a relatively selective inhibitor of iNOS155-158, and has been found to inhibit the diabetes-induced increase nitric oxide production and iNOS expression in retina ${ }^{145}$.

Aminoguanidine also has been found to inhibit the development of the microvascular lesions of diabetic retinopathy in diabetic dogs ${ }^{159}$ and rats ${ }^{160}$.The role of iNOS in the development of the early stages of diabetic retinopathy recently has been investigated directly using mice genetically deficient in iNOS161. In that study, wildtype diabetic mice developed the expected degeneration of retinal capillaries, as well as increase in leukostasis and superoxide generation. In contrast, diabetic mice deficient in iNOS did not develop these structural or functional abnormalities.

\section{Fas}

Fas levels are increased in retinas of diabetic rats132, 162. Blocking FasL in vivo has been shown to prevent endothelial cell damage, vascular leakage, and platelet accumulation in diabetes, suggesting that the Fas/FasL system might contribute to the diabetes-induced damage that contributes to the development of the retinopathy ${ }^{132}$, but its role in the development of retinal histopathology has not been assessed.

\section{Angiopoietin-1}

Angiopoietin-1 has been found to have anti-inflammatory actions, including inhibition of vascular permeability and adhesion protein expression ${ }^{163}$. When administered intravitreally to diabetic rats, angiopoietin-1 normalized blood-retinal barrier function, leukostasis and endothelial injury, and inhibited upregulation of retinal VEGF and ICAM-1mRNA and protein ${ }^{164}$.

\section{Hepatocyte Growth Factor (HGF)}

HGF in the etiopathogenesis of PDR remains to be elucidated. A lot of studies ${ }^{165-169}$ have found high intravitreous concentrations of HGF in patients with PDR. In the present study, 
we consider all these confounding factors in order to evaluate the vitreous levels of HGF in patients with PDR and to investigate its relationship with VEGF and retinopathy activity. A total of 28 diabetic patients with PDR, in whom a vitrectomy was performed, were included in the study. Thirty nondiabetic patients with other conditions requiring vitrectomy but in whom the retina was not directly affected by neovascularization served as a control group. Patients in whom intravitreous hemoglobin was detectable by spectophotometry were excluded. HGF and VEGF were determined by enzyme-linked immunosorbent assay. Vitreal levels of both VEGF and HGF were higher in diabetic patients with PDR than in the control group. These differences remained highly significant after adjusting for serum levels. To explore the influence of the breakdown of the blood-retinal barrier and, in consequence, the increased serum diffusion that occurs in PDR patients, the levels of both HGF and VEGF were normalized for total vitreal protein concentration. After correcting for total vitreous protein concentration, the ratio of VEGF to vitreal proteins remained significantly higher in diabetic patients with PDR than in the control group, respectively. However, the ratio of HGF to vitreal proteins was lower in diabetic patients than in nondiabetic control subjects. The lower intravitreous levels of HGF obtained after correcting for intravitreal proteins in patients with PDR in comparison with nondiabetic control subjects suggest that serum diffusion largely explains the differences detected in the intravitreous HGF levels between these groups. The vitreous concentrations of VEGF were higher in patients with active PDR than in patients with quiescent PDR. By contrast, vitreous HGF was not related to PDR activity ${ }^{170}$.

\section{Angiotensin II}

Angiogenesis, the growth of new vessels, is a physiologic process that occurs under normal conditions. During these processes, angiogenesis is well regulated by a balance of positive and negative factors. However, in various disease states, such as tumor progression, inflammation, and diabetic retinopathy, deregulated overactive angiogenesis contributes to disease progression ${ }^{171}$.Recent reports suggest that receptor tyrosine kinases (RTKs) of endothelial cells play a major role in both physiological and pathological angiogenesis 171,172 . Two distinct RTK subfamilies are characterized by their abundant expression of endothelium. One subfamily consists of VEGF receptors Flt-1/VEGF-R1, Flk-1/VEGF-R2, and Flt-4/VEGF-R3173-175. VEGF, also known as vascular permeability factor, is an endothelial cell-specific mitogen that induces angiogenesis and increases vasopermeability ${ }^{171}$.

The other endothelium-specific RTK subfamily is the Tie receptor family, consisting of Tie1 and Tie2 ${ }^{176}$. Tie1-null mice die in utero with defects that may implicate the hemodynamics of transcapillary fluid exchange177, 178. Similarly, Tie2-knockout mice die from day 9.5 to 10.5, because of immature vessels and lack of microvessel formation ${ }^{178,}$ 179. Unlike the VEGF receptor-knockout mouse ${ }^{180}$, the number of endothelial cells was normal, and tubular formation was detected in Tie2-knockout mice. A mutation in Tie2 in humans was reported to cause venous malformations, which are typically an imbalance of endothelial cells and smooth muscle cells ${ }^{181}$. These findings suggest that the Tie2 system has a role in endothelialstromal cell communication and in maturation and stabilization of vascular structures.

Ligands for the Tie2 receptor have been identified as angiopoietin (Ang)-1 and Ang2 182, 183 and, more recently,Ang3 and Ang4184. Ang1 phosphorylates Tie2 in cultured endothelial 
cells ${ }^{182}$, whereas Ang2 does not induce phosphorylation of Tie2, but rather inhibits the Ang1-induced phosphorylation of Tie2 in vascular endothelial cells ${ }^{183}$.Ang2-overexpressing transgenic mice die with vascular defects similar to Tie2- or Ang1-knockout mice178, 185 . These observations suggest that Ang2 acts as a natural antagonist of Tie2 by blocking receptor activation by Ang183. Recently, wide expression of Tie2 in the quiescent vasculature of adult tissues was reported ${ }^{186}$. A study using a corneal angiogenesis model revealed that Ang1 and Ang2 facilitates VEGF-induced neovascularization; Ang1 promotes vascular network maturation, whereas Ang2 initiates neovascularization ${ }^{187}$.These data support the idea that angiopoietins/Tie2 may have a role not only in embryonic angiogenesis, but also in postnatal angiogenesis.

The renin-angiotensin system (RAS) is known to be a key factor in the cardiovascular homeostasis that regulates blood pressure and fluid electrolyte balance ${ }^{188}$. RAS abnormalities have also been reported to play a role in the progression of diabetic retinopathy ${ }^{189}$. Angiotensin II has been reported to regulate cell growth by inducing several growth factors 190-192. In 1998 and 2000, Atsushi Otani et al reported that Angitensin II potentiates VEGF-mediated angiogenic activities through upregulation of VEGF-R2 expression in bovine retinal endothelial cells (BRECs) and upregulation of VEGF in bovine retinal pericytes (BRPs) 193, 194. As RAS played a major role in the retinal angiogenic abnormalities associated with diabetes, Atsushi Otani et al investigated the effect of angiotensin II (AII) on Ang1 and Ang2 expression in cultured bovine retinal endothelial cells(BRECs). Their results showed that AII stimulated Ang2 but not Ang1 mRNA expression in a dose- and time-dependent manner. This response was inhibited completely by angiotensin type 1 receptor (AT1) antagonist. AII increased the transcription of Ang2 mRNA, but did not change the half-life. Protein kinase C (PKC) inhibitor completely inhibited AIlinduced Ang2 expression, and the mitogen-activated protein kinase (MAPK) inhibitor also inhibited it. In addition, the upregulation of Ang2 in an AII-induced in vivo rat corneal neovascularization model was also confirmed. These data suggest that AII stimulates Ang2 expression through AT1 receptor-mediated PKC and MAPK pathways in BREC, and AII may play a novel role in retinal neovascularization ${ }^{195}$.

\section{Glial cell-derived cytokines}

BRB is a biological unit of retinal vessels with a well-differentiated network, including glial cells such as astrocytes and Müller cells, maintaining the retinal microenvironment and low permeability. The substantial apparatus of the BRB is a barrier comprised of tight junctions between the capillary endothelial cells that strictly regulate the paracellular pathways between the cells ${ }^{196}$. BRB breakdown is closely associated with a number of retinal diseases such as diabetic retinopathy, which is characterized by vascular leakage due to increased vascular permeability in its early pathogenesis ${ }^{197}$.

Hich is believed to be a critical factor in the development of diabetic retinopathy ${ }^{12,15,48}$. However, the molecular pharmacology that directly inhibits activated VEGF has not been proven to satisfactorily block microangiopathy in diabetic retinopathy ${ }^{198,}$, 199. Glial cell linederived neurotrophic factor (GDNF) was originally identified as a neurotrophic differentiation factor for dopaminergic neurons in the central nervous system and retina.The certain advanced glycation end products could increase the vascular permeability of the BRB in vitro by the induction of VEGF and reduction of GDNF expression from glial cells 
have been demonstrated, suggesting that phenotypic alteration of glial cells in diabetes is responsible for the BRB breakdown $200-202$.

The vitamin A metabolite all-trans retinoic acid (ATRA) is a potent regulator of cell differentiation and an essential signaling molecule in embryonic development and throughout life. A study has shown that ATRA can differentiate pluripotent embryonal carcinoma cells into neuronal and glial tissues and that it plays an important role in the induction of GDNF responsiveness in these cells ${ }^{203}$. Nami Nishikiori et al demonstrated that retinoic acid receptor (RAR)a stimulants preferentially act on glial cells, resulting in the enhanced expression of glial cell line-derived neurotrophic factor (GDNF) through recruitment of the RARa-driven trans-acting coactivator to the 5 -flanking region of the gene promoter. Conversely, RARa decreases expression of VEGF/vascular permeability factor. These gene expression alterations causally limit vascular permeability by modulating the tight junction function of capillary endothelium in a paracrine manner in vitro. The phenotypic transformation of glial cells mediated by RARa is sufficient for significant reductions of vascular leakage in the diabetic retina, suggesting that RARa antagonizes the loss of tight junction integrity induced by diabetes. These findings reveal that glial cellderived cytokines such as GDNF and VEGF regulate BRB function, implying that the glial cell can be a possible therapeutic target in diabetic retinopathy 204.

\section{References}

[1] Miwa K, Nakamura J, Hamada Y, Naruse K, Nakashima E, Kato K, et al. The role of polyol pathway in glucose-induced apoptosis of cultured retinal pericytes. Diabetes Res Clin Pract. 2003; 60(1): 1-9.

[2] Yang Y, Hayden MR, Sowers S, Bagree SV, Sowers JR. Retinal redox stress and remodeling in cardiometabolic syndrome and diabetes. Oxid Med Cell Longev. 2010; 3(6): 392-403.

[3] Sims DE. The pericyte--a review. Tissue Cell. 1986; 18(2): 153-74.

[4] Ferris FL, 3rd, Patz A. Macular edema. A complication of diabetic retinopathy. Surv Ophthalmol. 1984; 28 Suppl: 452-61.

[5] Antcliff RJ, Marshall J. The pathogenesis of edema in diabetic maculopathy. Semin Ophthalmol. 1999; 14(4): 223-32.

[6] Ciulla TA, Harris A, Latkany P, Piper HC, Arend O, Garzozi H, et al. Ocular perfusion abnormalities in diabetes. Acta Ophthalmol Scand. 2002; 80(5): 468-77.

[7] Cogan DG, Toussaint D, Kuwabara T. Retinal vascular patterns. IV. Diabetic retinopathy. Arch Ophthalmol. 1961; 66: 366-78.

[8] Kuwabara T, Cogan DG. Retinal vascular patterns. VI. Mural cells of the retinal capillaries. Arch Ophthalmol. 1963; 69: 492-502.

[9] Speiser P, Gittelsohn AM, Patz A. Studies on diabetic retinopathy. 3. Influence of diabetes on intramural pericytes. Arch Ophthalmol. 1968; 80(3): 332-7.

[10] Miyamoto K, Ogura Y. Pathogenetic potential of leukocytes in diabetic retinopathy. Semin Ophthalmol. 1999; 14(4): 233-9.

[11] Miyamoto K, Khosrof S, Bursell SE, Rohan R, Murata T, Clermont AC, et al. Prevention of leukostasis and vascular leakage in streptozotocin-induced diabetic retinopathy via intercellular adhesion molecule-1 inhibition. Proc Natl Acad Sci U S A. 1999; 96(19): 10836-41. 
[12] Murata T, Nakagawa K, Khalil A, Ishibashi T, Inomata H, Sueishi K. The relation between expression of vascular endothelial growth factor and breakdown of the blood-retinal barrier in diabetic rat retinas. Lab Invest. 1996; 74(4): 819-25.

[13] Levy AP, Levy NS, Wegner S, Goldberg MA. Transcriptional regulation of the rat vascular endothelial growth factor gene by hypoxia. J Biol Chem. 1995; 270(22): 13333-40.

[14] Miller JW, Adamis AP, Aiello LP. Vascular endothelial growth factor in ocular neovascularization and proliferative diabetic retinopathy. Diabetes Metab Rev. 1997; 13(1): 37-50.

[15] Aiello LP, Avery RL, Arrigg PG, Keyt BA, Jampel HD, Shah ST, et al. Vascular endothelial growth factor in ocular fluid of patients with diabetic retinopathy and other retinal disorders. N Engl J Med. 1994; 331(22): 1480-7.

[16] Tilton RG, Kawamura T, Chang KC, Ido Y, Bjercke RJ, Stephan CC, et al. Vascular dysfunction induced by elevated glucose levels in rats is mediated by vascular endothelial growth factor. J Clin Invest. 1997; 99(9): 2192-202.

[17] Leinonen H, Matikainen E, Juntunen J. Permeability and morphology of skeletal muscle capillaries in type 1 (insulin-dependent) diabetes mellitus. Diabetologia. 1982; 22(3): 158-62.

[18] Sone H, Kawakami Y, Okuda Y, Sekine Y, Honmura S, Matsuo K, et al. Ocular vascular endothelial growth factor levels in diabetic rats are elevated before observable retinal proliferative changes. Diabetologia. 1997; 40(6): 726-30.

[19] Gerhardinger C, Brown LF, Roy S, Mizutani M, Zucker CL, Lorenzi M. Expression of vascular endothelial growth factor in the human retina and in nonproliferative diabetic retinopathy. Am J Pathol. 1998; 152(6): 1453-62.

[20] Segawa Y, Shirao Y, Yamagishi S, Higashide T, Kobayashi M, Katsuno K, et al. Upregulation of retinal vascular endothelial growth factor mRNAs in spontaneously diabetic rats without ophthalmoscopic retinopathy. A possible participation of advanced glycation end products in the development of the early phase of diabetic retinopathy. Ophthalmic Res. 1998; 30(6): 333-9.

[21] Tolentino MJ, Miller JW, Gragoudas ES, Jakobiec FA, Flynn E, Chatzistefanou K, et al. Intravitreous injections of vascular endothelial growth factor produce retinal ischemia and microangiopathy in an adult primate. Ophthalmology. 1996; 103(11): 1820-8.

[22] Tolentino MJ, McLeod DS, Taomoto M, Otsuji T, Adamis AP, Lutty GA. Pathologic features of vascular endothelial growth factor-induced retinopathy in the nonhuman primate. Am J Ophthalmol. 2002; 133(3): 373-85.

[23] Yang Y, Andresen BT, Yang K, Zhang Y, Li X, Wang H. Association of vascular endothelial growth factor $-634 \mathrm{C} / \mathrm{G}$ polymorphism and diabetic retinopathy in type 2 diabetic Han Chinese. Exp Biol Med (Maywood). 2010; 235(10): 1204-11.

[24] Rakoczy PE, Brankov M, Fonceca A, Zaknich T, Rae BC, Lai CM. Enhanced recombinant adeno-associated virus-mediated vascular endothelial growth factor expression in the adult mouse retina: a potential model for diabetic retinopathy. Diabetes. 2003; 52(3): 857-63.

[25] Montero JA, Ruiz-Moreno JM, Correa ME. Intravitreal anti-VEGF drugs as adjuvant therapy in diabetic retinopathy surgery. Curr Diabetes Rev. 2011; 7(3): 176-84. 
[26] Kenyon BM, Voest EE, Chen CC, Flynn E, Folkman J, D'Amato RJ. A model of angiogenesis in the mouse cornea. Invest Ophthalmol Vis Sci. 1996; 37(8): 1625-32.

[27] Anglade E, Csaky KG. Recombinant adenovirus-mediated gene transfer into the adult rat retina. Curr Eye Res. 1998; 17(3): 316-21.

[28] Spilsbury K, Garrett KL, Shen WY, Constable IJ, Rakoczy PE. Overexpression of vascular endothelial growth factor (VEGF) in the retinal pigment epithelium leads to the development of choroidal neovascularization. Am J Pathol. 2000; 157(1): 135-44.

[29] Okamoto N, Tobe T, Hackett SF, Ozaki H, Vinores MA, LaRochelle W, et al. Transgenic mice with increased expression of vascular endothelial growth factor in the retina: a new model of intraretinal and subretinal neovascularization. Am J Pathol. 1997; 151(1): 281-91.

[30] Ohno-Matsui K, Hirose A, Yamamoto S, Saikia J, Okamoto N, Gehlbach P, et al. Inducible expression of vascular endothelial growth factor in adult mice causes severe proliferative retinopathy and retinal detachment. Am J Pathol. 2002; 160(2): 711-9.

[31] Hata $Y$, Nakagawa K, Ishibashi T, Inomata H, Ueno H, Sueishi K. Hypoxia-induced expression of vascular endothelial growth factor by retinal glial cells promotes in vitro angiogenesis. Virchows Arch. 1995; 426(5): 479-86.

[32] Aiello LP, Northrup JM, Keyt BA, Takagi H, Iwamoto MA. Hypoxic regulation of vascular endothelial growth factor in retinal cells. Arch Ophthalmol. 1995; 113(12): 1538-44.

[33] Yan Q, Li Y, Hendrickson A, Sage EH. Regulation of retinal capillary cells by basic fibroblast growth factor, vascular endothelial growth factor, and hypoxia. In Vitro Cell Dev Biol Anim. 2001; 37(1): 45-9.

[34] Connolly DT. Vascular permeability factor: a unique regulator of blood vessel function. J Cell Biochem. 1991; 47(3): 219-23.

[35] Esser S, Wolburg K, Wolburg H, Breier G, Kurzchalia T, Risau W. Vascular endothelial growth factor induces endothelial fenestrations in vitro. J Cell Biol. 1998; 140(4): 947-59.

[36] Lu M, Amano S, Miyamoto K, Garland R, Keough K, Qin W, et al. Insulin-induced vascular endothelial growth factor expression in retina. Invest Ophthalmol Vis Sci. 1999; 40(13): 3281-6.

[37] Pettersson A, Nagy JA, Brown LF, Sundberg C, Morgan E, Jungles S, et al. Heterogeneity of the angiogenic response induced in different normal adult tissues by vascular permeability factor/vascular endothelial growth factor. Lab Invest. 2000; 80(1): 99-115.

[38] Emoto M, Anno T, Sato Y, Tanabe K, Okuya S, Tanizawa Y, et al. Troglitazone treatment increases plasma vascular endothelial growth factor in diabetic patients and its mRNA in 3T3-L1 adipocytes. Diabetes. 2001; 50(5): 1166-70.

[39] Biscetti F, Gaetani E, Flex A, Aprahamian T, Hopkins T, Straface G, et al. Selective activation of peroxisome proliferator-activated receptor (PPAR)alpha and PPAR gamma induces neoangiogenesis through a vascular endothelial growth factordependent mechanism. Diabetes. 2008; 57(5): 1394-404.

[40] Becerra SP. Structure-function studies on PEDF. A noninhibitory serpin with neurotrophic activity. Adv Exp Med Biol. 1997; 425: 223-37. 
[41] Spranger J, Osterhoff M, Reimann M, Mohlig M, Ristow M, Francis MK, et al. Loss of the antiangiogenic pigment epithelium-derived factor in patients with angiogenic eye disease. Diabetes. 2001; 50(12): 2641-5.

[42] Duh EJ, Yang HS, Suzuma I, Miyagi M, Youngman E, Mori K, et al. Pigment epithelium-derived factor suppresses ischemia-induced retinal neovascularization and VEGF-induced migration and growth. Invest Ophthalmol Vis Sci. 2002; 43(3): 821-9.

[43] Amano S, Yamagishi S, Inagaki Y, Nakamura K, Takeuchi M, Inoue H, et al. Pigment epithelium-derived factor inhibits oxidative stress-induced apoptosis and dysfunction of cultured retinal pericytes. Microvasc Res. 2005; 69(1-2): 45-55.

[44] Yamagishi S, Inagaki Y, Amano S, Okamoto T, Takeuchi M, Makita Z. Pigment epithelium-derived factor protects cultured retinal pericytes from advanced glycation end product-induced injury through its antioxidative properties. Biochem Biophys Res Commun. 2002; 296(4): 877-82.

[45] Gao G, Li Y, Fant J, Crosson CE, Becerra SP, Ma JX. Difference in ischemic regulation of vascular endothelial growth factor and pigment epithelium--derived factor in brown norway and sprague dawley rats contributing to different susceptibilities to retinal neovascularization. Diabetes. 2002; 51(4): 1218-25.

[46] Patel JI, Tombran-Tink J, Hykin PG, Gregor ZJ, Cree IA. Vitreous and aqueous concentrations of proangiogenic, antiangiogenic factors and other cytokines in diabetic retinopathy patients with macular edema: Implications for structural differences in macular profiles. Exp Eye Res. 2006; 82(5): 798-806.

[47] Dawson DW, Volpert OV, Gillis P, Crawford SE, Xu H, Benedict W, et al. Pigment epithelium-derived factor: a potent inhibitor of angiogenesis. Science. 1999; 285(5425): 245-8.

[48] Pierce EA, Avery RL, Foley ED, Aiello LP, Smith LE. Vascular endothelial growth factor/vascular permeability factor expression in a mouse model of retinal neovascularization. Proc Natl Acad Sci U S A. 1995; 92(3): 905-9.

[49] Gao G, Li Y, Zhang D, Gee S, Crosson C, Ma J. Unbalanced expression of VEGF and PEDF in ischemia-induced retinal neovascularization. FEBS Lett. 2001; 489(2-3): 270-6.

[50] Chen H, Jia W, Xu X, Fan Y, Zhu D, Wu H, et al. Upregulation of PEDF expression by PARP inhibition contributes to the decrease in hyperglycemia-induced apoptosis in HUVECs. Biochem Biophys Res Commun. 2008; 369(2): 718-24.

[51] Yang H, Xu Z, Iuvone PM, Grossniklaus HE. Angiostatin decreases cell migration and vascular endothelium growth factor (VEGF) to pigment epithelium derived factor (PEDF) RNA ratio in vitro and in a murine ocular melanoma model. Mol Vis. 2006; 12: 511-7.

[52] Tsao YP, Ho TC, Chen SL, Cheng HC. Pigment epithelium-derived factor inhibits oxidative stress-induced cell death by activation of extracellular signal-regulated kinases in cultured retinal pigment epithelial cells. Life Sci. 2006; 79(6): 545-50.

[53] King GL, Suzuma K. Pigment-epithelium-derived factor--a key coordinator of retinal neuronal and vascular functions. N Engl J Med. 2000; 342(5): 349-51.

[54] Spranger J, Hammes HP, Preissner KT, Schatz H, Pfeiffer AF. Release of the angiogenesis inhibitor angiostatin in patients with proliferative diabetic 
retinopathy: association with retinal photocoagulation. Diabetologia. 2000; 43(11): 1404-7.

[55] Meyer-Schwickerath R, Pfeiffer A, Blum WF, Freyberger H, Klein M, Losche C, et al. Vitreous levels of the insulin-like growth factors I and II, and the insulin-like growth factor binding proteins 2 and 3 , increase in neovascular eye disease. Studies in nondiabetic and diabetic subjects. J Clin Invest. 1993; 92(6): 2620-5.

[56] Taniwaki T, Hirashima N, Becerra SP, Chader GJ, Etcheberrigaray R, Schwartz JP. Pigment epithelium-derived factor protects cultured cerebellar granule cells against glutamate-induced neurotoxicity. J Neurochem. 1997; 68(1): 26-32.

[57] Pignolo RJ, Cristofalo VJ, Rotenberg MO. Senescent WI-38 cells fail to express EPC-1, a gene induced in young cells upon entry into the G0 state. J Biol Chem. 1993; 268(12): 8949-57.

[58] Stellmach V, Crawford SE, Zhou W, Bouck N. Prevention of ischemia-induced retinopathy by the natural ocular antiangiogenic agent pigment epithelium-derived factor. Proc Natl Acad Sci U S A. 2001; 98(5): 2593-7.

[59] Zheng Z, Chen H, Ke G, Fan Y, Zou H, Sun X, et al. Protective effect of perindopril on diabetic retinopathy is associated with decreased vascular endothelial growth factor-to-pigment epithelium-derived factor ratio: involvement of a mitochondriareactive oxygen species pathway. Diabetes. 2009; 58(4): 954-64.

[60] Kato K, Osawa H, Ochi M, Kusunoki Y, Ebisui O, Ohno K, et al. Serum total and high molecular weight adiponectin levels are correlated with the severity of diabetic retinopathy and nephropathy. Clin Endocrinol (Oxf). 2008; 68(3): 442-9.

[61] Higuchi A, Ohashi K, Shibata R, Sono-Romanelli S, Walsh K, Ouchi N. Thiazolidinediones reduce pathological neovascularization in ischemic retina via an adiponectin-dependent mechanism. Arterioscler Thromb Vasc Biol. 2010; 30(1): 46-53.

[62] Ouchi N, Kihara S, Arita Y, Nishida M, Matsuyama A, Okamoto Y, et al. Adipocytederived plasma protein, adiponectin, suppresses lipid accumulation and class A scavenger receptor expression in human monocyte-derived macrophages. Circulation. 2001; 103(8): 1057-63.

[63] Ouchi N, Kihara S, Arita Y, Maeda K, Kuriyama H, Okamoto Y, et al. Novel modulator for endothelial adhesion molecules: adipocyte-derived plasma protein adiponectin. Circulation. 1999; 100(25): 2473-6.

[64] Sheetz MJ, King GL. Molecular understanding of hyperglycemia's adverse effects for diabetic complications. JAMA. 2002; 288(20): 2579-88.

[65] Spranger J, Pfeiffer AF. New concepts in pathogenesis and treatment of diabetic retinopathy. Exp Clin Endocrinol Diabetes. 2001; 109 Suppl 2: S438-50.

[66] Gariano RF, Gardner TW. Retinal angiogenesis in development and disease. Nature. 2005; 438(7070): 960-6.

[67] Ouchi N, Kihara S, Funahashi T, Matsuzawa Y, Walsh K. Obesity, adiponectin and vascular inflammatory disease. Curr Opin Lipidol. 2003; 14(6): 561-6.

[68] Scherer PE, Williams S, Fogliano M, Baldini G, Lodish HF. A novel serum protein similar to C1q, produced exclusively in adipocytes. J Biol Chem. 1995; 270(45): 26746-9. 
[69] Shibata R, Sato K, Pimentel DR, Takemura Y, Kihara S, Ohashi K, et al. Adiponectin protects against myocardial ischemia-reperfusion injury through AMPK- and COX2-dependent mechanisms. Nat Med. 2005; 11(10): 1096-103.

[70] Maeda N, Shimomura I, Kishida K, Nishizawa H, Matsuda M, Nagaretani H, et al. Dietinduced insulin resistance in mice lacking adiponectin/ACRP30. Nat Med. 2002; 8(7): 731-7.

[71] Kubota N, Terauchi Y, Yamauchi T, Kubota T, Moroi M, Matsui J, et al. Disruption of adiponectin causes insulin resistance and neointimal formation. J Biol Chem. 2002; 277(29): 25863-6.

[72] Sharma K, Ramachandrarao S, Qiu G, Usui HK, Zhu Y, Dunn SR, et al. Adiponectin regulates albuminuria and podocyte function in mice. J Clin Invest. 2008; 118(5): 1645-56.

[73] Shibata R, Ouchi N, Kihara S, Sato K, Funahashi T, Walsh K. Adiponectin stimulates angiogenesis in response to tissue ischemia through stimulation of amp-activated protein kinase signaling. J Biol Chem. 2004; 279(27): 28670-4.

[74] Nishimura M, Izumiya Y, Higuchi A, Shibata R, Qiu J, Kudo C, et al. Adiponectin prevents cerebral ischemic injury through endothelial nitric oxide synthase dependent mechanisms. Circulation. 2008; 117(2): 216-23.

[75] Matsushita K, Yatsuya H, Tamakoshi K, Wada K, Otsuka R, Zhang H, et al. Inverse association between adiponectin and C-reactive protein in substantially healthy Japanese men. Atherosclerosis. 2006; 188(1): 184-9.

[76] Engeli S, Feldpausch M, Gorzelniak K, Hartwig F, Heintze U, Janke J, et al. Association between adiponectin and mediators of inflammation in obese women. Diabetes. 2003; 52(4): 942-7.

[77] Kumada M, Kihara S, Sumitsuji S, Kawamoto T, Matsumoto S, Ouchi N, et al. Association of hypoadiponectinemia with coronary artery disease in men. Arterioscler Thromb Vasc Biol. 2003; 23(1): 85-9.

[78] Matsuda M, Kawasaki F, Yamada K, Kanda Y, Saito M, Eto M, et al. Impact of adiposity and plasma adipocytokines on diabetic angiopathies in Japanese Type 2 diabetic subjects. Diabet Med. 2004; 21(8): 881-8.

[79] Yilmaz MI, Sonmez A, Acikel C, Celik T, Bingol N, Pinar M, et al. Adiponectin may play a part in the pathogenesis of diabetic retinopathy. Eur J Endocrinol. 2004; 151(1): 135-40.

[80] Higuchi A, Ohashi K, Kihara S, Walsh K, Ouchi N. Adiponectin suppresses pathological microvessel formation in retina through modulation of tumor necrosis factor-alpha expression. Circ Res. 2009; 104(9): 1058-65.

[81] Matsuzawa Y, Funahashi T, Nakamura T. Molecular mechanism of metabolic syndrome $X$ : contribution of adipocytokines adipocyte-derived bioactive substances. Ann N Y Acad Sci. 1999; 892: 146-54.

[82] Friedman JM, Halaas JL. Leptin and the regulation of body weight in mammals. Nature. 1998; 395(6704): 763-70.

[83] Mantzoros CS. The role of leptin in human obesity and disease: a review of current evidence. Ann Intern Med. 1999; 130(8): 671-80.

[84] Sierra-Honigmann MR, Nath AK, Murakami C, Garcia-Cardena G, Papapetropoulos A, Sessa WC, et al. Biological action of leptin as an angiogenic factor. Science. 1998; 281(5383): 1683-6. 
[85] Bouloumie A, Drexler HC, Lafontan M, Busse R. Leptin, the product of Ob gene, promotes angiogenesis. Circ Res. 1998; 83(10): 1059-66.

[86] Uckaya G, Ozata M, Bayraktar Z, Erten V, Bingol N, Ozdemir IC. Is leptin associated with diabetic retinopathy? Diabetes Care. 2000; 23(3): 371-6.

[87] Gariano RF, Nath AK, D'Amico DJ, Lee T, Sierra-Honigmann MR. Elevation of vitreous leptin in diabetic retinopathy and retinal detachment. Invest Ophthalmol Vis Sci. 2000; 41(11): 3576-81.

[88] Suganami E, Takagi H, Ohashi H, Suzuma K, Suzuma I, Oh H, et al. Leptin stimulates ischemia-induced retinal neovascularization: possible role of vascular endothelial growth factor expressed in retinal endothelial cells. Diabetes. 2004; 53(9): 2443-8.

[89] Yano K, Bauchat JR, Liimatta MB, Clemmons DR, Duan C. Down-regulation of protein kinase $C$ inhibits insulin-like growth factor I-induced vascular smooth muscle cell proliferation, migration, and gene expression. Endocrinology. 1999; 140(10): 4622-32.

[90] Matsuzawa Y. Therapy Insight: adipocytokines in metabolic syndrome and related cardiovascular disease. Nat Clin Pract Cardiovasc Med. 2006; 3(1): 35-42.

[91] DeBosch BJ, Baur E, Deo BK, Hiraoka M, Kumagai AK. Effects of insulin-like growth factor-1 on retinal endothelial cell glucose transport and proliferation. J Neurochem. 2001; 77(4): 1157-67.

[92] Sharp PS, Fallon TJ, Brazier OJ, Sandler L, Joplin GF, Kohner EM. Long-term follow-up of patients who underwent yttrium-90 pituitary implantation for treatment of proliferative diabetic retinopathy. Diabetologia. 1987; 30(4): 199-207.

[93] Growth Hormone Antagonist for Proliferative Diabetic Retinopathy Study Group.The effect of a growth hormone receptor antagonist drug on proliferative diabetic retinopathy. Ophthalmology. 2001; 108(12): 2266-72.

[94] The effect of a growth hormone receptor antagonist drug on proliferative diabetic retinopathy. Ophthalmology. 2001; 108(12): 2266-72.

[95] Grant MB, Mames RN, Fitzgerald C, Hazariwala KM, Cooper-DeHoff R, Caballero S, et al. The efficacy of octreotide in the therapy of severe nonproliferative and early proliferative diabetic retinopathy: a randomized controlled study. Diabetes Care. 2000; 23(4): 504-9.

[96] Vincent JA, Mohr S. Inhibition of caspase-1/interleukin-1beta signaling prevents degeneration of retinal capillaries in diabetes and galactosemia. Diabetes. 2007; 56(1): 224-30.

[97] Krady JK, Basu A, Allen CM, Xu Y, LaNoue KF, Gardner TW, et al. Minocycline reduces proinflammatory cytokine expression, microglial activation, and caspase-3 activation in a rodent model of diabetic retinopathy. Diabetes. 2005; 54(5): 1559-65.

[98] Kowluru RA, Odenbach S. Role of interleukin-1beta in the development of retinopathy in rats: effect of antioxidants. Invest Ophthalmol Vis Sci. 2004; 45(11): 4161-6.

[99] Kowluru RA, Odenbach S. Role of interleukin-1beta in the pathogenesis of diabetic retinopathy. Br J Ophthalmol. 2004; 88(10): 1343-7.

[100] Mohr S, Xi X, Tang J, Kern TS. Caspase activation in retinas of diabetic and galactosemic mice and diabetic patients. Diabetes. 2002; 51(4): 1172-9.

[101] Fan F, Stoeltzing O, Liu W, McCarty MF, Jung YD, Reinmuth N, et al. Interleukin1 beta regulates angiopoietin-1 expression in human endothelial cells. Cancer Res. 2004; 64(9): 3186-90. 
[102] Romeo G, Liu WH, Asnaghi V, Kern TS, Lorenzi M. Activation of nuclear factorkappaB induced by diabetes and high glucose regulates a proapoptotic program in retinal pericytes. Diabetes. 2002; 51(7): 2241-8.

[103] Dinarello CA, Donath MY, Mandrup-Poulsen T. Role of IL-1beta in type 2 diabetes. Curr Opin Endocrinol Diabetes Obes. 2010; 17(4): 314-21.

[104] Yu JG, Javorschi S, Hevener AL, Kruszynska YT, Norman RA, Sinha M, et al. The effect of thiazolidinediones on plasma adiponectin levels in normal, obese, and type 2 diabetic subjects. Diabetes. 2002; 51(10): 2968-74.

[105] Zhou L, Sun H, Xu J, Kang J. [Level of vascular endothelial growth factor and interleukin-6 in aqueous humor in diabetic retinopathy patients.]. Yan Ke Xue Bao. 2010; 25(1): 26-30.

[106] Lee JH, Lee W, Kwon OH, Kim JH, Kwon OW, Kim KH, et al. Cytokine profile of peripheral blood in type 2 diabetes mellitus patients with diabetic retinopathy. Ann Clin Lab Sci. 2008; 38(4): 361-7.

[107] Rojas M, Zhang W, Lee DL, Romero MJ, Nguyen DT, Al-Shabrawey M, et al. Role of IL-6 in angiotensin II-induced retinal vascular inflammation. Invest Ophthalmol Vis Sci. 2010; 51(3): 1709-18.

[108] Nakazawa T, Hisatomi T, Nakazawa C, Noda K, Maruyama K, She H, et al. Monocyte chemoattractant protein 1 mediates retinal detachment-induced photoreceptor apoptosis. Proc Natl Acad Sci U S A. 2007; 104(7): 2425-30.

[109] Oh IK, Kim SW, Oh J, Lee TS, Huh K. Inflammatory and angiogenic factors in the aqueous humor and the relationship to diabetic retinopathy. Curr Eye Res. 2010; 35(12): 1116-27.

[110] Tang S, Le-Ruppert KC, Gabel VP. Expression of intercellular adhesion molecule-1 (ICAM-1) and vascular cell adhesion molecule-1 (VCAM-1) on proliferating vascular endothelial cells in diabetic epiretinal membranes. Br J Ophthalmol. 1994; 78(5): 370-6.

[111] Limb GA, Chignell AH, Green W, LeRoy F, Dumonde DC. Distribution of TNF alpha and its reactive vascular adhesion molecules in fibrovascular membranes of proliferative diabetic retinopathy. Br J Ophthalmol. 1996; 80(2): 168-73.

[112] Ferrara N. Leukocyte adhesion. Missing link in angiogenesis. Nature. 1995; 376(6540): 467.

[113] Koch AE, Halloran MM, Haskell CJ, Shah MR, Polverini PJ. Angiogenesis mediated by soluble forms of E-selectin and vascular cell adhesion molecule-1. Nature. 1995; 376(6540): 517-9.

[114] Olson JA, Whitelaw CM, McHardy KC, Pearson DW, Forrester JV. Soluble leucocyte adhesion molecules in diabetic retinopathy stimulate retinal capillary endothelial cell migration. Diabetologia. 1997; 40(10): 1166-71.

[115] Barile GR, Chang SS, Park LS, Reppucci VS, Schiff WM, Schmidt AM. Soluble cellular adhesion molecules in proliferative vitreoretinopathy and proliferative diabetic retinopathy. Curr Eye Res. 1999; 19(3): 219-27.

[116] Bradham DM, Igarashi A, Potter RL, Grotendorst GR. Connective tissue growth factor: a cysteine-rich mitogen secreted by human vascular endothelial cells is related to the SRC-induced immediate early gene product CEF-10. J Cell Biol. 1991; 114(6): 1285-94. 
[117] Grotendorst GR. Connective tissue growth factor: a mediator of TGF-beta action on fibroblasts. Cytokine Growth Factor Rev. 1997; 8(3): 171-9.

[118] Blom IE, Goldschmeding R, Leask A. Gene regulation of connective tissue growth factor: new targets for antifibrotic therapy? Matrix Biol. 2002; 21(6): 473-82.

[119] Leask A, Holmes A, Abraham DJ. Connective tissue growth factor: a new and important player in the pathogenesis of fibrosis. Curr Rheumatol Rep. 2002; 4(2): $136-42$.

[120] Hinton DR, Spee C, He S, Weitz S, Usinger W, LaBree L, et al. Accumulation of NH2terminal fragment of connective tissue growth factor in the vitreous of patients with proliferative diabetic retinopathy. Diabetes Care. 2004; 27(3): 758-64.

[121] Kita T, Hata Y, Kano K, Miura M, Nakao S, Noda Y, et al. Transforming growth factorbeta2 and connective tissue growth factor in proliferative vitreoretinal diseases: possible involvement of hyalocytes and therapeutic potential of Rho kinase inhibitor. Diabetes. 2007; 56(1): 231-8.

[122] Kireeva ML, Latinkic BV, Kolesnikova TV, Chen CC, Yang GP, Abler AS, et al. Cyr61 and Fisp12 are both ECM-associated signaling molecules: activities, metabolism, and localization during development. Exp Cell Res. 1997; 233(1): 63-77.

[123] Shimo T, Nakanishi T, Kimura Y, Nishida T, Ishizeki K, Matsumura T, et al. Inhibition of endogenous expression of connective tissue growth factor by its antisense oligonucleotide and antisense RNA suppresses proliferation and migration of vascular endothelial cells. J Biochem. 1998; 124(1): 130-40.

[124] Babic AM, Chen CC, Lau LF. Fisp12/mouse connective tissue growth factor mediates endothelial cell adhesion and migration through integrin alphavbeta3, promotes endothelial cell survival, and induces angiogenesis in vivo. Mol Cell Biol. 1999; 19(4): 2958-66.

[125] Shimo T, Nakanishi T, Nishida T, Asano M, Sasaki A, Kanyama M, et al. Involvement of CTGF, a hypertrophic chondrocyte-specific gene product, in tumor angiogenesis. Oncology. 2001; 61(4): 315-22.

[126] He S, Jin ML, Worpel V, Hinton DR. A role for connective tissue growth factor in the pathogenesis of choroidal neovascularization. Arch Ophthalmol. 2003; 121(9): 1283-8.

[127] Watanabe D, Takagi H, Suzuma K, Oh H, Ohashi H, Honda Y. Expression of connective tissue growth factor and its potential role in choroidal neovascularization. Retina. 2005; 25(7): 911-8.

[128] Kita T, Hata Y, Miura M, Kawahara S, Nakao S, Ishibashi T. Functional characteristics of connective tissue growth factor on vitreoretinal cells. Diabetes. 2007; 56(5): 1421-8.

[129] McLeod DS, Lefer DJ, Merges C, Lutty GA. Enhanced expression of intracellular adhesion molecule- 1 and P-selectin in the diabetic human retina and choroid. Am J Pathol. 1995; 147(3): 642-53.

[130] Schroder S, Palinski W, Schmid-Schonbein GW. Activated monocytes and granulocytes, capillary nonperfusion, and neovascularization in diabetic retinopathy. Am J Pathol. 1991; 139(1): 81-100.

[131] Miyamoto K, Hiroshiba N, Tsujikawa A, Ogura Y. In vivo demonstration of increased leukocyte entrapment in retinal microcirculation of diabetic rats. Invest Ophthalmol Vis Sci. 1998; 39(11): 2190-4. 
[132] Joussen AM, Murata T, Tsujikawa A, Kirchhof B, Bursell SE, Adamis AP. Leukocytemediated endothelial cell injury and death in the diabetic retina. Am J Pathol. 2001; 158(1): 147-52.

[133] Joussen AM, Poulaki V, Mitsiades N, Cai WY, Suzuma I, Pak J, et al. Suppression of FasFasL-induced endothelial cell apoptosis prevents diabetic blood-retinal barrier breakdown in a model of streptozotocin-induced diabetes. FASEB J. 2003; 17(1): 76-8.

[134] Kohner EM, Henkind P. Correlation of fluorescein angiogram and retinal digest in diabetic retinopathy. Am J Ophthalmol. 1970; 69(3): 403-14.

[135] Barouch FC, Miyamoto K, Allport JR, Fujita K, Bursell SE, Aiello LP, et al. Integrinmediated neutrophil adhesion and retinal leukostasis in diabetes. Invest Ophthalmol Vis Sci. 2000; 41(5): 1153-8.

[136] Joussen AM, Poulaki V, Le ML, Koizumi K, Esser C, Janicki H, et al. A central role for inflammation in the pathogenesis of diabetic retinopathy. FASEB J. 2004; 18(12): 1450-2.

[137] Harris AG, Skalak TC, Hatchell DL. Leukocyte-capillary plugging and network resistance are increased in skeletal muscle of rats with streptozotocin-induced hyperglycemia. Int J Microcirc Clin Exp. 1994; 14(3): 159-66.

[138] Kelly LW, Barden CA, Tiedeman JS, Hatchell DL. Alterations in viscosity and filterability of whole blood and blood cell subpopulations in diabetic cats. Exp Eye Res. 1993; 56(3): 341-7.

[139] Zheng L, Szabo C, Kern TS. Poly(ADP-ribose) polymerase is involved in the development of diabetic retinopathy via regulation of nuclear factor-kappaB. Diabetes. 2004; 53(11): 2960-7.

[140] Lu M, Perez VL, Ma N, Miyamoto K, Peng HB, Liao JK, et al. VEGF increases retinal vascular ICAM-1 expression in vivo. Invest Ophthalmol Vis Sci. 1999; 40(8): 1808-12.

[141] Hubbard AK, Rothlein R. Intercellular adhesion molecule-1 (ICAM-1) expression and cell signaling cascades. Free Radic Biol Med. 2000; 28(9): 1379-86.

[142] Chen W, Jump DB, Grant MB, Esselman WJ, Busik JV. Dyslipidemia, but not hyperglycemia, induces inflammatory adhesion molecules in human retinal vascular endothelial cells. Invest Ophthalmol Vis Sci. 2003; 44(11): 5016-22.

[143] Zheng L, Howell SJ, Hatala DA, Huang K, Kern TS. Salicylate-based antiinflammatory drugs inhibit the early lesion of diabetic retinopathy. Diabetes. 2007; 56(2): 337-45.

[144] Kowluru RA, Tang J, Kern TS. Abnormalities of retinal metabolism in diabetes and experimental galactosemia. VII. Effect of long-term administration of antioxidants on the development of retinopathy. Diabetes. 2001; 50(8): 1938-42.

[145] Kowluru RA, Engerman RL, Case GL, Kern TS. Retinal glutamate in diabetes and effect of antioxidants. Neurochem Int. 2001; 38(5): 385-90.

[146] Du Y, Smith MA, Miller CM, Kern TS. Diabetes-induced nitrative stress in the retina, and correction by aminoguanidine. J Neurochem. 2002; 80(5): 771-9.

[147] Abu El-Asrar AM, Desmet S, Meersschaert A, Dralands L, Missotten L, Geboes K. Expression of the inducible isoform of nitric oxide synthase in the retinas of human subjects with diabetes mellitus. Am J Ophthalmol. 2001; 132(4): 551-6.

[148] Du Y, Sarthy VP, Kern TS. Interaction between NO and COX pathways in retinal cells exposed to elevated glucose and retina of diabetic rats. Am J Physiol Regul Integr Comp Physiol. 2004; 287(4): R735-41. 
[149] Carmo A, Cunha-Vaz JG, Carvalho AP, Lopes MC. Nitric oxide synthase activity in retinas from non-insulin-dependent diabetic Goto-Kakizaki rats: correlation with blood-retinal barrier permeability. Nitric Oxide. 2000; 4(6): 590-6.

[150] do Carmo A, Lopes C, Santos M, Proenca R, Cunha-Vaz J, Carvalho AP. Nitric oxide synthase activity and L-arginine metabolism in the retinas from streptozotocininduced diabetic rats. Gen Pharmacol. 1998; 30(3): 319-24.

[151] Kowluru RA. Retinal metabolic abnormalities in diabetic mouse: comparison with diabetic rat. Curr Eye Res. 2002; 24(2): 123-8.

[152] Kowluru RA, Engerman RL, Kern TS. Abnormalities of retinal metabolism in diabetes or experimental galactosemia VIII. Prevention by aminoguanidine. Curr Eye Res. 2000; 21(4): 814-9.

[153] Kowluru RA. Effect of reinstitution of good glycemic control on retinal oxidative stress and nitrative stress in diabetic rats. Diabetes. 2003; 52(3): 818-23.

[154] Joussen AM, Poulaki V, Qin W, Kirchhof B, Mitsiades N, Wiegand SJ, et al. Retinal vascular endothelial growth factor induces intercellular adhesion molecule-1 and endothelial nitric oxide synthase expression and initiates early diabetic retinal leukocyte adhesion in vivo. Am J Pathol. 2002; 160(2): 501-9.

[155] Park JW, Park SJ, Park SH, Kim KY, Chung JW, Chun MH, et al. Up-regulated expression of neuronal nitric oxide synthase in experimental diabetic retina. Neurobiol Dis. 2006; 21(1): 43-9.

[156] Tilton RG, Pugliese G, LaRose LS, Faller AM, Chang K, Province MA, et al. Discordant effects of the aldose reductase inhibitor, sorbinil, on vascular structure and function in chronically diabetic and galactosemic rats. J Diabet Complications. 1991; 5(4): 230-7.

[157] Corbett JA, Tilton RG, Chang K, Hasan KS, Ido Y, Wang JL, et al. Aminoguanidine, a novel inhibitor of nitric oxide formation, prevents diabetic vascular dysfunction. Diabetes. 1992; 41(4): 552-6.

[158] Hasan K, Heesen BJ, Corbett JA, McDaniel ML, Chang K, Allison W, et al. Inhibition of nitric oxide formation by guanidines. Eur J Pharmacol. 1993; 249(1): 101-6.

[159] Misko TP, Moore WM, Kasten TP, Nickols GA, Corbett JA, Tilton RG, et al. Selective inhibition of the inducible nitric oxide synthase by aminoguanidine. Eur J Pharmacol. 1993; 233(1): 119-25.

[160] Kern TS, Engerman RL. Pharmacological inhibition of diabetic retinopathy: aminoguanidine and aspirin. Diabetes. 2001; 50(7): 1636-42.

[161] Kern TS, Tang J, Mizutani M, Kowluru RA, Nagaraj RH, Romeo G, et al. Response of capillary cell death to aminoguanidine predicts the development of retinopathy: comparison of diabetes and galactosemia. Invest Ophthalmol Vis Sci. 2000; 41(12): 3972-8.

[162] Zheng L, Du Y, Miller C, Gubitosi-Klug RA, Ball S, Berkowitz BA, et al. Critical role of inducible nitric oxide synthase in degeneration of retinal capillaries in mice with streptozotocin-induced diabetes. Diabetologia. 2007; 50(9): 1987-96.

[163] Joussen AM, Poulaki V, Mitsiades N, Kirchhof B, Koizumi K, Dohmen S, et al. Nonsteroidal anti-inflammatory drugs prevent early diabetic retinopathy via TNFalpha suppression. FASEB J. 2002; 16(3): 438-40. 
[164] Gamble JR, Drew J, Trezise L, Underwood A, Parsons M, Kasminkas L, et al. Angiopoietin-1 is an antipermeability and anti-inflammatory agent in vitro and targets cell junctions. Circ Res. 2000; 87(7): 603-7.

[165] Joussen AM, Poulaki V, Tsujikawa A, Qin W, Qaum T, Xu Q, et al. Suppression of diabetic retinopathy with angiopoietin-1. Am J Pathol. 2002; 160(5): 1683-93.

[166] Nishimura M, Ikeda T, Ushiyama M, Nanbu A, Kinoshita S, Yoshimura M. Increased vitreous concentrations of human hepatocyte growth factor in proliferative diabetic retinopathy. J Clin Endocrinol Metab. 1999; 84(2): 659-62.

[167] Katsura Y, Okano T, Noritake M, Kosano H, Nishigori H, Kado S, et al. Hepatocyte growth factor in vitreous fluid of patients with proliferative diabetic retinopathy and other retinal disorders. Diabetes Care. 1998; 21(10): 1759-63.

[168] Canton A, Burgos R, Hernandez C, Mateo C, Segura RM, Mesa J, et al. Hepatocyte growth factor in vitreous and serum from patients with proliferative diabetic retinopathy. Br J Ophthalmol. 2000; 84(7): 732-5.

[169] Umeda N, Ozaki H, Hayashi H, Kondo H, Uchida H, Oshima K. Non-paralleled increase of hepatocyte growth factor and vascular endothelial growth factor in the eyes with angiogenic and nonangiogenic fibroproliferation. Ophthalmic Res. 2002; 34(1): 43-7.

[170] Mitamura Y, Takeuchi S, Matsuda A, Tagawa Y, Mizue Y, Nishihira J. Hepatocyte growth factor levels in the vitreous of patients with proliferative vitreoretinopathy. Am J Ophthalmol. 2000; 129(5): 678-80.

[171] Simo R, Lecube A, Garcia-Arumi J, Carrasco E, Hernandez C. Hepatocyte growth factor in the vitreous fluid of patients with proliferative diabetic retinopathy: its relationship with vascular endothelial growth factor and retinopathy activity. Diabetes Care. 2004; 27(1): 287-8.

[172] Risau W. Mechanisms of angiogenesis. Nature. 1997; 386(6626): 671-4.

[173] Hanahan D. Signaling vascular morphogenesis and maintenance. Science. 1997; 277(5322): 48-50.

[174] Millauer B, Wizigmann-Voos S, Schnurch H, Martinez R, Moller NP, Risau W, et al. High affinity VEGF binding and developmental expression suggest Flk-1 as a major regulator of vasculogenesis and angiogenesis. Cell. 1993; 72(6): 835-46.

[175] Joukov V, Pajusola K, Kaipainen A, Chilov D, Lahtinen I, Kukk E, et al. A novel vascular endothelial growth factor, VEGF-C, is a ligand for the Flt4 (VEGFR-3) and KDR (VEGFR-2) receptor tyrosine kinases. EMBO J. 1996; 15(7): 1751.

[176] de Vries C, Escobedo JA, Ueno H, Houck K, Ferrara N, Williams LT. The fms-like tyrosine kinase, a receptor for vascular endothelial growth factor. Science. 1992; 255(5047): 989-91.

[177] Sato TN, Qin Y, Kozak CA, Audus KL. Tie-1 and tie-2 define another class of putative receptor tyrosine kinase genes expressed in early embryonic vascular system. Proc Natl Acad Sci U S A. 1993; 90(20): 9355-8.

[178] Puri MC, Rossant J, Alitalo K, Bernstein A, Partanen J. The receptor tyrosine kinase TIE is required for integrity and survival of vascular endothelial cells. EMBO J. 1995; 14(23): 5884-91.

[179] Sato TN, Tozawa Y, Deutsch U, Wolburg-Buchholz K, Fujiwara Y, Gendron-Maguire $\mathrm{M}$, et al. Distinct roles of the receptor tyrosine kinases Tie-1 and Tie-2 in blood vessel formation. Nature. 1995; 376(6535): 70-4. 
[180] Dumont DJ, Gradwohl G, Fong GH, Puri MC, Gertsenstein M, Auerbach A, et al. Dominant-negative and targeted null mutations in the endothelial receptor tyrosine kinase, tek, reveal a critical role in vasculogenesis of the embryo. Genes Dev. 1994; 8(16): 1897-909.

[181] Shalaby F, Rossant J, Yamaguchi TP, Gertsenstein M, Wu XF, Breitman ML, et al. Failure of blood-island formation and vasculogenesis in Flk-1-deficient mice. Nature. 1995; 376(6535): 62-6.

[182] Vikkula M, Boon LM, Carraway KL, 3rd, Calvert JT, Diamonti AJ, Goumnerov B, et al. Vascular dysmorphogenesis caused by an activating mutation in the receptor tyrosine kinase TIE2. Cell. 1996; 87(7): 1181-90.

[183] Davis S, Aldrich TH, Jones PF, Acheson A, Compton DL, Jain V, et al. Isolation of angiopoietin-1, a ligand for the TIE2 receptor, by secretion-trap expression cloning. Cell. 1996; 87(7): 1161-9.

[184] Maisonpierre PC, Suri C, Jones PF, Bartunkova S, Wiegand SJ, Radziejewski C, et al. Angiopoietin-2, a natural antagonist for Tie2 that disrupts in vivo angiogenesis. Science. 1997; 277(5322): 55-60.

[185] Oh SJ, Jeltsch MM, Birkenhager R, McCarthy JE, Weich HA, Christ B, et al. VEGF and VEGF-C: specific induction of angiogenesis and lymphangiogenesis in the differentiated avian chorioallantoic membrane. Dev Biol. 1997; 188(1): 96-109.

[186] Suri C, Jones PF, Patan S, Bartunkova S, Maisonpierre PC, Davis S, et al. Requisite role of angiopoietin-1, a ligand for the TIE2 receptor, during embryonic angiogenesis. Cell. 1996; 87(7): 1171-80.

[187] Wong AL, Haroon ZA, Werner S, Dewhirst MW, Greenberg CS, Peters KG. Tie2 expression and phosphorylation in angiogenic and quiescent adult tissues. Circ Res. 1997; 81(4): 567-74.

[188] Asahara T, Chen D, Takahashi T, Fujikawa K, Kearney M, Magner M, et al. Tie2 receptor ligands, angiopoietin-1 and angiopoietin-2, modulate VEGF-induced postnatal neovascularization. Circ Res. 1998; 83(3): 233-40.

[189] Dzau VJ. Molecular biology of angiotensin II biosynthesis and receptors. Can J Cardiol. 1995; 11 Suppl F: 21F-6F.

[190] Chaturvedi N, Sjolie AK, Stephenson JM, Abrahamian H, Keipes M, Castellarin A, et al. Effect of lisinopril on progression of retinopathy in normotensive people with type 1 diabetes. The EUCLID Study Group. EURODIAB Controlled Trial of Lisinopril in Insulin-Dependent Diabetes Mellitus. Lancet. 1998; 351(9095): 28-31.

[191] Naftilan AJ, Pratt RE, Dzau VJ. Induction of platelet-derived growth factor A-chain and c-myc gene expressions by angiotensin II in cultured rat vascular smooth muscle cells. J Clin Invest. 1989; 83(4): 1419-24.

[192] Delafontaine P, Lou H. Angiotensin II regulates insulin-like growth factor I gene expression in vascular smooth muscle cells. J Biol Chem. 1993; 268(22): 16866-70.

[193] Tomita H, Egashira K, Ohara Y, Takemoto M, Koyanagi M, Katoh M, et al. Early induction of transforming growth factor-beta via angiotensin II type 1 receptors contributes to cardiac fibrosis induced by long-term blockade of nitric oxide synthesis in rats. Hypertension. 1998; 32(2): 273-9.

[194] Otani A, Takagi H, Suzuma K, Honda Y. Angiotensin II potentiates vascular endothelial growth factor-induced angiogenic activity in retinal microcapillary endothelial cells. Circ Res. 1998; 82(5): 619-28. 
[195] Otani A, Takagi H, Oh H, Suzuma K, Matsumura M, Ikeda E, et al. Angiotensin IIstimulated vascular endothelial growth factor expression in bovine retinal pericytes. Invest Ophthalmol Vis Sci. 2000; 41(5): 1192-9.

[196] Otani A, Takagi H, Oh H, Koyama S, Honda Y. Angiotensin II induces expression of the Tie2 receptor ligand, angiopoietin-2, in bovine retinal endothelial cells. Diabetes. 2001; 50(4): 867-75.

[197] Sawada N, Murata M, Kikuchi K, Osanai M, Tobioka H, Kojima T, et al. Tight junctions and human diseases. Med Electron Microsc. 2003; 36(3): 147-56.

[198] Frank RN. Diabetic retinopathy. N Engl J Med. 2004; 350(1): 48-58.

[199] Ng EW, Shima DT, Calias P, Cunningham ET, Jr., Guyer DR, Adamis AP. Pegaptanib, a targeted anti-VEGF aptamer for ocular vascular disease. Nat Rev Drug Discov. 2006; 5(2): 123-32.

[200] Comer GM, Ciulla TA. Pharmacotherapy for diabetic retinopathy. Curr Opin Ophthalmol. 2004; 15(6): 508-18.

[201] Miyajima H, Osanai M, Chiba H, Nishikiori N, Kojima T, Ohtsuka K, et al. Glyceraldehyde-derived advanced glycation end-products preferentially induce VEGF expression and reduce GDNF expression in human astrocytes. Biochem Biophys Res Commun. 2005; 330(2): 361-6.

[202] Igarashi Y, Chiba H, Utsumi H, Miyajima H, Ishizaki T, Gotoh T, et al. Expression of receptors for glial cell line-derived neurotrophic factor (GDNF) and neurturin in the inner blood-retinal barrier of rats. Cell Struct Funct. 2000; 25(4): 237-41.

[203] Igarashi Y, Utsumi H, Chiba H, Yamada-Sasamori Y, Tobioka H, Kamimura Y, et al. Glial cell line-derived neurotrophic factor induces barrier function of endothelial cells forming the blood-brain barrier. Biochem Biophys Res Commun. 1999; 261(1): 108-12.

[204] Thang SH, Kobayashi M, Matsuoka I. Regulation of glial cell line-derived neurotrophic factor responsiveness in developing rat sympathetic neurons by retinoic acid and bone morphogenetic protein-2. J Neurosci. 2000; 20(8): 2917-25.

[205] Nishikiori N, Osanai M, Chiba H, Kojima T, Mitamura Y, Ohguro H, et al. Glial cellderived cytokines attenuate the breakdown of vascular integrity in diabetic retinopathy. Diabetes. 2007; 56(5): 1333-40. 


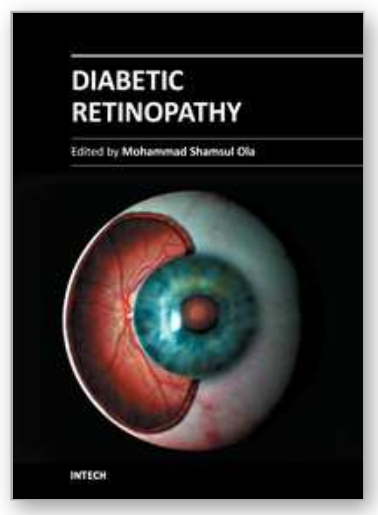

\author{
Diabetic Retinopathy \\ Edited by Dr. Mohammad Shamsul Ola
}

ISBN 978-953-51-0044-7

Hard cover, 356 pages

Publisher InTech

Published online 24, February, 2012

Published in print edition February, 2012

The aim of this book is to provide a comprehensive overview of current concepts in pathogenesis, diagnosis and treatments of diabetic retinopathy. It provides a collection of topics written by excellent authors, covering discussions on advances in understanding of pathophysiology, immunological factors and emerging concepts, relating to clinical aspects and treatment strategies. The contents of the book will not only provide a resource for our knowledge but also improve diagnosis and treatment options for those patients who suffer vision loss due to diabetic retinopathy.

\title{
How to reference
}

In order to correctly reference this scholarly work, feel free to copy and paste the following:

Ying Yang, Ying Zhang and Yiping Li (2012). Inflammation and Angiogenesis in Diabetic Retinopathy, Diabetic Retinopathy, Dr. Mohammad Shamsul Ola (Ed.), ISBN: 978-953-51-0044-7, InTech, Available from: http://www.intechopen.com/books/diabetic-retinopathy/inflammation-and-angiogenesis-in-diabetic-retinopathy

\section{INTECH}

open science | open minds

\section{InTech Europe}

University Campus STeP Ri

Slavka Krautzeka 83/A

51000 Rijeka, Croatia

Phone: +385 (51) 770447

Fax: +385 (51) 686166

www.intechopen.com

\section{InTech China}

Unit 405, Office Block, Hotel Equatorial Shanghai

No.65, Yan An Road (West), Shanghai, 200040, China

中国上海市延安西路65号上海国际贵都大饭店办公楼 405 单元

Phone: +86-21-62489820

Fax: +86-21-62489821 
(C) 2012 The Author(s). Licensee IntechOpen. This is an open access article distributed under the terms of the Creative Commons Attribution 3.0 License, which permits unrestricted use, distribution, and reproduction in any medium, provided the original work is properly cited. 